\title{
GMR
}

\section{Effect of a high-concentrate diet on milk components and mammary health in Holstein dairy cows}

\author{
Z.L. Xie ${ }^{1,2,3}$, J. Zhang' ${ }^{2}$, D.M. Zhang ${ }^{3}$, J.F. Li $^{3}$ and Y.H. Lin ${ }^{3}$ \\ ${ }^{1}$ Jinshan College of Fujian Agriculture and Forestry University, \\ Cangshan District, Fuzhou City, Fujian Province, China \\ ${ }^{2}$ Key Laboratory of Traditional Chinese Veterinary Medicine and Animal \\ Health in Fujian Province, Fujian Agriculture and Forestry University, \\ Cangshan District, Fuzhou City, Fujian Province, China \\ ${ }^{3}$ Beef Cattle Feeding Teaching Experimental Base, \\ Jinshan College of Fujian Agriculture and Forestry University, Baisha Town, \\ Minhou county, Fuzhou City, Fujian Province, China \\ Corresponding author: Z.L. Xie \\ E-mail: 312498721@qq.com
}

Genet. Mol. Res. 16 (1): gmr16019204

Received September 6, 2016

Accepted December 12, 2016

Published March 22, 2017

DOI http://dx.doi.org/10.4238/gmr16019204

Copyright (C) 2017 The Authors. This is an open-access article distributed under the terms of the Creative Commons Attribution ShareAlike (CC BY-SA) 4.0 License

ABSTRACT. In order to evaluate the milk yield, milk quality,
and health of dairy cows fed a high-concentrate $(\mathrm{HC})$ diet, eight
lactating Holstein dairy cattle were randomly assigned to HC or
low-concentrate (LC) diet groups and fed for 50 days, and the auto-
control studying before and after treatment with the two diets was
used. During the experiment, plasma and milk samples were collected
and measured. With regard to milk component, HC feeding led to
higher milk production $(\mathrm{P}<0.05)$, but significantly lower milk protein
percentage $(\mathrm{P}<0.05)$, milk protein yield $(\mathrm{P}<0.05)$, and milk fat

Genetics and Molecular Research 16 (1): gmr16019204 
percentage $(\mathrm{P}<0.05)$ throughout the five periods than LC feeding. Milk somatic cell count and $\mathrm{N}$-acetyl-D-glucosaminidase activity ( $\mathrm{P}$ $<0.01)$ were higher than those observed under LC feeding. mRNA expression levels of interleukin-8 (IL-8), C-C motif chemokine ligand (CCL5), and lactalbumin alpha ( $\alpha$-LA) were investigated by qPCR and found to be significantly lower $(\mathrm{P}<0.01)$ in cattle fed the $\mathrm{HC}$ diet. The amino acid content was analyzed by high performance liquid chromatography (HPLC), and the content of Asp $(\mathrm{P}<0.01)$, Gln (P $<0.01)$, Ala $(\mathrm{P}<0.05)$, Leu $(\mathrm{P}<0.05)$, Lys $(\mathrm{P}<0.05)$, and Ile $(\mathrm{P}<$ $0.01)$ was significantly lower in the HC group, whereas the content of $\operatorname{Arg}(\mathrm{P}<0.05)$ and Phe $(\mathrm{P}<0.01)$ was significantly higher. These results suggest that the $\mathrm{HC}$ diet might have an important influence on mammary health. The amino acid content was lower, suggesting that depletion of amino acids, resulting in depleted milk protein, affects milk quality.

Key words: Holstein dairy cattle; Milk quality; Lactation; Amino acid metabolism; High concentrate diet 5

\section{INTRODUCTION}

Dairy production plays an important role in global agriculture within the top 10 leading dairy companies in 2009 (Whitley, 2010). Most international dairy companies agree that high-concentrate $(\mathrm{HC})$ diets should be provided to increase milk production. However, selective feeding affects the health of cows (Miglior et al., 2005; Valde et al., 2007). Previous studies have found that health reduces the yield and quality of milk, and ultimately affects the profitability of the dairy farm. DeGraves and Fetrow (1993) estimated that the costs associated with mastitis in the United States dairy industry exceeded 2 billion dollars per year. The economic impact of mastitis on dairy cattle is related to the increase in somatic cell count (SCC) in milk, which increases the treatment costs and risk of having to discard milk (Brouillette and Malouin, 2005). However, sub-clinical mastitis is ubiquitous in dairy farms, and occurs following the cessation of incomplete milking (Capuco et al., 2003). Mansfeld et al. (2001) demonstrated that sub-clinical mastitis increased SCC and enhanced N-acetyl-Dglucosaminidase (NAG) activity, and that there was a significant correlation between these effects. Leitner et al. (2001) and Seifu et al. (2007) showed that the correlation between SCC and NAG activity $(\mathrm{r}=0.85, \mathrm{P}<0.01 ; \mathrm{r}=0.88, \mathrm{P}<0.01$, respectively) was able to reflect the existence of sub-clinical mastitis.

Milk protein composition is important for achieving optimal yield and texture when milk is metabolized, such as in cheese and yoghurt, and is thus a good index of milk quality. During lactation, the main function of amino acids is to synthesize milk protein in the body, or their transformation into other nitrogen-containing biotic activator. Thus, amino acid metabolism is prolific in the mammary glands of dairy cows. In the current study, we used HC diets to evaluate the in vitro efficacy of mammary amino acid metabolism by milk aminograms and cytokine gene expression in mammary tissue, in order to explain the effect of mammary health and milk quality on $\mathrm{HC}$ feeding in lactating cows.

Genetics and Molecular Research 16 (1): gmr16019204 


\section{MATERIAL AND METHODS}

\section{Animals, experimental treatments, and feeding}

Eight lactating Holstein dairy cows $[578 \pm 21 \mathrm{Kg}$ body weight (BW), mean \pm standard error (SE) of the mean] in their second lactation (221 \pm 19 days, means \pm SE) were used in a randomized complete block design. Prior to the start of the experiment, cows were grouped into two blocks $(\mathrm{N}=8 \mathrm{each})$ according to the stage of lactation. The cows were assigned to receive a low-concentrate diet [LC; concentrate-to-forage $(\mathrm{C}: \mathrm{F})$ ratios of 4:6; Table 1]. To minimize the effect of lactation stage on the results, cows were enrolled in the experiment when each reached, on average, the above-specified characteristics. At the end of the LC diet period, the cattle were assigned to receive a $\mathrm{HC}$ diet. To minimize the effect of lactation stage on the results, cattle were transitioned to receive the HC diet in equal increments over 5 days, until the end of experimental period 5. The eight self-control dairy cows of treatment group in high-concentrate diet and low-concentrate diet. The average intake of each cow during the baseline period was then provided for the remaining five periods (150 days, periods 1, 2, 3,4 , and 5). Throughout the lactation period, cattle had unlimited access to fresh water and were milked thrice daily in their stalls. All experimental procedures were approved by the Animal Care Committee of the University in accordance with the guidelines established by the People's Republic of China.

\begin{tabular}{|c|c|c|}
\hline \multirow[b]{2}{*}{ Ingredients, \% dry matter (DM) } & \multicolumn{2}{|c|}{$\begin{array}{c}\text { Diets } \\
\text { HC LC }\end{array}$} \\
\hline & & \\
\hline Forage & 15.00 & 10.00 \\
\hline Lucerne & 0.00 & 25.00 \\
\hline Ensile & 25.00 & 25.00 \\
\hline Corn & 32.90 & 21.97 \\
\hline Wheat bran & 3.00 & 2.00 \\
\hline Soybean meal & 22.40 & 14.97 \\
\hline Calcium Hydrogen Phosphate & 0.10 & 0.08 \\
\hline Limestone & 0.60 & 0.40 \\
\hline Salt & 0.40 & 0.28 \\
\hline Premix & 0.50 & 0.32 \\
\hline \multicolumn{3}{|l|}{ Chemical composition, $\%$ of DM } \\
\hline $\mathrm{NE}(\mathrm{MJ} / \mathrm{Kg})$ & 6.52 & 6.32 \\
\hline $\mathrm{CP}$ & 17.27 & 17.24 \\
\hline NDF & 35.07 & 38.81 \\
\hline ADF & 19.31 & 23.66 \\
\hline Ash & 4.71 & 6.45 \\
\hline $\mathrm{Ca}$ & 0.44 & 0.78 \\
\hline $\mathrm{P}$ & 0.33 & 0.3 \\
\hline
\end{tabular}

\section{Plasma and milk sampling, milk production, and milk components}

Blood samples were collected from each cow using a jugular catheter after feeding for $4 \mathrm{~h}$ and placed into tubes. Anticoagulant factor was used to harvest plasma. Blood samples were immediately placed on ice, centrifuged at $3000 \mathrm{~g}$ for $20 \mathrm{~min}$ and frozen at $-20^{\circ} \mathrm{C}$ until analysis.

Milking took place at 04:30 and 17:00 h daily during lactation. Individual milk yields

Genetics and Molecular Research 16 (1): gmr16019204 
(Kg) were recorded and milk samples were collected at each milking. The first three squirts of milk were discarded, then approximately $5 \mathrm{~mL}$ milk was placed into a sterile tube and used to determine the milk fat and protein concentrations by Integrated Milk Testing ${ }^{\mathrm{TM}}$ Milkoscan 4000 (Foss Electric, Hillerod, Denmark). Additionally, the SCC of milk was determined using an electronic cell counter (Fossomatic, Foss Electric, Hillerod, Denmark) (Booth et al., 1995). Milk NAGase activity was determined using a kit (Jiancheng, Nanjing) according to the manufacturer instructions.

\section{Plasma amino acid analysis}

Milk samples were placed on ice, centrifuged at $3500 \mathrm{~g}$ for $30 \mathrm{~min}$ at room temperature for phase separation. The stratum medium was carefully collected and placed in a fresh 2 -mL tube. Samples were centrifuged again at $3500 \mathrm{~g}$ for $30 \mathrm{~min}$ at room temperature for further phase separation, and the stratum medium fluid was collected and frozen at $-20^{\circ} \mathrm{C}$ until analysis. The treatment of high performance liquid chromatography (HPLC) samples and injection methods were as follows: 1) milk was centrifuged at $3500 \mathrm{~g}$ for $10 \mathrm{~min}$ at $4{ }^{\circ} \mathrm{C}$ for phase separation; 2) the under-layer fluid (milk-samples-new) was carefully collected and placed in a fresh 2-mL tube; 3 ) acetonitrile (HPLC solvents, USA) was added to milk samples based on an acetonitrile: milk-samples-new ratio of 2:1 and then mixed by vortex; 4) samples were then incubated at $4^{\circ} \mathrm{C}$ for $30 \mathrm{~min}$ and centrifuged at $12,000 \mathrm{~g}$ for $30 \mathrm{~min}$ at $4^{\circ} \mathrm{C}$; 5) the supernatant was carefully collected and placed at $4^{\circ} \mathrm{C}$ until analysis; 6) pre-column derivatization was performed as follows: $20 \mu \mathrm{L}$ milk-samples-new: O-phthalaldehyde (OPA) (1:2) was added and samples were incubated for $2 \mathrm{~min} ; 7)$ stop buffer $(10 \mu \mathrm{L})$ was added, samples were vortexed thoroughly, and injected.

\section{Mammary sampling and gene expression}

Mammary glands were collected by biopsy in the first period and at the end of the experiment. Mammary tissue was collected, washed twice with cold physiological saline $(0.9 \% \mathrm{NaCl})$ solution to remove blood and other possible contaminants, and then transferred into liquid $\mathrm{N}$ and stored at $-80^{\circ} \mathrm{C}$ until analysis. Slaughter and sampling procedures complied with the Guidelines on Ethical Treatment of Experimental Animals (2006) No. 398 set by the Ministry of Science and Technology of China.

The methods for total RNA extraction and RNase treatment have been described elsewhere (Xie et al., 2015a). Total RNA was isolated from mammary glands using TRIZOL (Invitrogen, Beijing, China), and then quantified by measuring the absorbance at $260 \mathrm{~nm}$. cDNA was generated from $2 \mu \mathrm{g}$ total RNA by M-MLV reverse transcriptase (Promega, USA) as indicated by the manufacturer. qPCR was performed using a SYBR Mix kit (Roche, Germany) according to the manufacturer instructions in a Bio-Rad MyiQ ${ }^{\mathrm{TM}}$ Detection System (Applied Biosystems). The abundances of interleukin-8 (IL-8), C-C motif chemokine ligand (CCL5), and lactalbumin alpha ( $\alpha$-LA), and $\beta$-actin mRNA were determined. The thermal cycling conditions were as follows: $1 \mathrm{~min}$ at $50^{\circ} \mathrm{C}$, and $10 \mathrm{~min}$ at $95^{\circ} \mathrm{C}$, followed by 40 cycles at $95^{\circ} \mathrm{C}$ for $25 \mathrm{~s}, 60^{\circ} \mathrm{C}$ for $30 \mathrm{~s}$, and $72^{\circ} \mathrm{C}$ for $30 \mathrm{~s}$ min in a Bio-Rad MyiQ ${ }^{\mathrm{TM}}$ Detection System (Applied Biosystems, USA). The amount of target mRNA was calculated by normalization according to the $2^{-\Delta \Delta C t}$ method (Xie et al., 2015a,b). The gene primers synthesized and used are shown in Table 2.

Genetics and Molecular Research 16 (1): gmr16019204 
Table 2. Nucleotide sequences of specific primers used in this study.

\begin{tabular}{|c|c|c|c|c|c|}
\hline Primers & Gen Bank accession No. & Primers sequence $\left(5^{\prime} \rightarrow 3^{\prime}\right)$ & Orientation & Product length (bp) & Annealing temperature $\left({ }^{\circ} \mathrm{C}\right)$ \\
\hline \multirow[t]{2}{*}{$\beta$-actin } & \multirow[t]{2}{*}{ AY141970.1 } & ccagttcgecatggatgatg & Forward & \multirow[t]{2}{*}{230} & \multirow[t]{2}{*}{59} \\
\hline & & cgtgctcaatggggtacttg & Reverse & & \\
\hline \multirow[t]{2}{*}{ IL-8 } & \multirow[t]{2}{*}{ JN559767.1 } & ccaatggaaacgaggtctgc & Forward & \multirow[t]{2}{*}{214} & \multirow[t]{2}{*}{60} \\
\hline & & caccagacccacacagtaca & Reverse & & \\
\hline \multirow[t]{2}{*}{ CCL5 } & \multirow[t]{2}{*}{ NM_175827.2 } & gagttgagctagggtggagg & Forward & \multirow[t]{2}{*}{216} & \multirow[t]{2}{*}{60} \\
\hline & & cggagcttagagacetcetg & Reverse & & \\
\hline \multirow[t]{2}{*}{$\alpha-\mathrm{LA}$} & \multirow[t]{2}{*}{ NM_174378.2 } & ttccgggagctgaaagactt & Forward & \multirow[t]{2}{*}{171} & \multirow[t]{2}{*}{59} \\
\hline & & ctggtcgtctttgcaccaaa & Reverse & & \\
\hline
\end{tabular}

\section{Statistical analysis}

At least three replicates were used for each sample to evaluate gene expression by using a MIXED model with repeated measures in SPSS-16.0. Milk production, milk protein, and milk fat were analyzed by the paired-samples T test. The SCC and NAG content was analysis by the paired-samples $t$-test. The results are expressed as means \pm SEM and differences were considered significant when $\mathrm{P}<0.05$.

\section{RESULTS}

\section{Milk production and milk components}

Milk production and milk components are summarized in Figure 1A and 1B. Dry matter intake was significantly lower $(\mathrm{P}<0.01)$ in the $\mathrm{HC}$ group than in the LC group, from $15.43 \pm$ $0.167 \mathrm{~kg} /$ day in the LC group to $14.38 \pm 0.185 \mathrm{~kg} /$ day in the HC group (Figure 1A). The HC diet significantly decreased milk protein yield $(\mathrm{P}<0.05)$ through all five periods (Figure $1 \mathrm{~B}$ ), but there was a clear increase in milk production $(\mathrm{P}<0.05$, Figure $1 \mathrm{~A})$. HC-feeding significantly decreased the milk protein percentage $(\mathrm{P}<0.05)$ and the milk fat percentage $(\mathrm{P}<0.05)$, whereas there was no difference in milk fat yield $(\mathrm{P}>0.05)$ versus LC-feeding (Figure 1B). Figure 2 shows that the SCC and NAGase activity were higher in the milk of HC cows than in that of $\mathrm{LC}$ cows $(\mathrm{P}<0.01)$. The milk NAGase content was higher than that in plasma under the $\mathrm{HC}$ diet treatment $(\mathrm{P}<0.05)$.

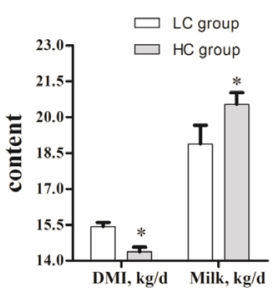

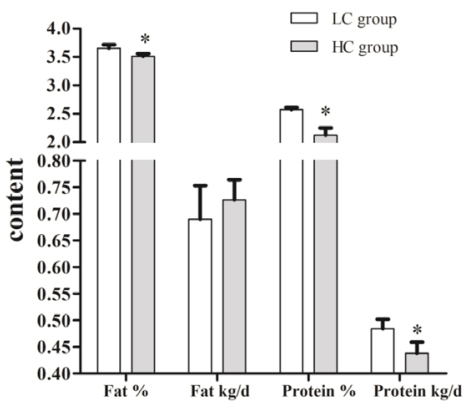

B

Figure 1. Effects of feeding the high-concentrate (HC) diet or low-concentrate (LC) diet over time on feed intake, milk production, and milk components. A. DMI and milk production; B. milk fat and milk protein. Data are expressed as mean $\pm \mathrm{SE}$ compared with the LC cattle. $* \mathrm{P}<0.05$ and $* * \mathrm{P}<0.01$ indicate statistically significant differences when compared with the LC group.

Genetics and Molecular Research 16 (1): gmr16019204 


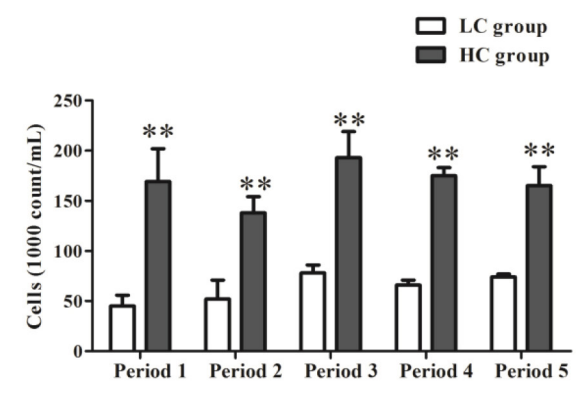

A

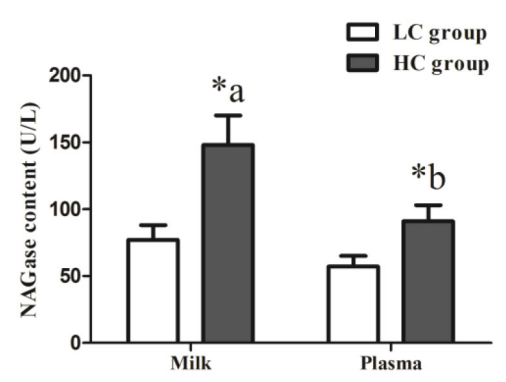

B

Figure 2. Determination of milk somatic cell count and NAGase activity between HC-feeding and LC-feeding cattle. A. Milk somatic cell count; B. milk NAGase activity. The experiments were repeated three times. Data are presented as mean $\pm \mathrm{SE}, * \mathrm{P}<0.05$ indicates statistically significant differences when compared with the LC group. $* * \mathrm{P}<0.01$ indicates statistically significant differences when compared with the LC group. Lowercase letters indicate statistically significant differences $(\mathrm{P}<0.05)$.

\section{Aminogram}

Fifteen different standard amino acids were separated in the chromatogram, and their parameters were determined. For each amino acid, the correlation coefficient exceeded 0.996. The difference determination results showed that the intraday relative standard deviation (RSD) ranged from 2.93 to $5.45 \%$, the interday RSD ranged from 3.39 to $5.88 \%$, with all values less than $6.0 \%$. Thus, the experimental conditions and precision were consistent with the HPLC detection requirements.

Figure 3 shows that $\mathrm{HC}$ feeding led to significantly higher content of Asp ( $\mathrm{P}<$ $0.01)$, Gln $(\mathrm{P}<0.01)$, Ala $(\mathrm{P}<0.05)$, Leu $(\mathrm{P}<0.05)$, Lys $(\mathrm{P}<0.05)$, and Ile $(\mathrm{P}<0.01)$, but significantly lower content of $\operatorname{Arg}(\mathrm{P}<0.05)$ and $\mathrm{Phe}(\mathrm{P}<0.01)$. There were no differences in the content of other amino acids (Glu, Ser, Thr, and Trp) between the HC and LC treatments $(\mathrm{P}>0.05)$. Among the amino acids measured, there was an increase in the content of aromatic amino acids (Phe), but a decrease in the content of branched chain amino acids (Ile and Leu) when cattle were fed the $\mathrm{HC}$ diet.

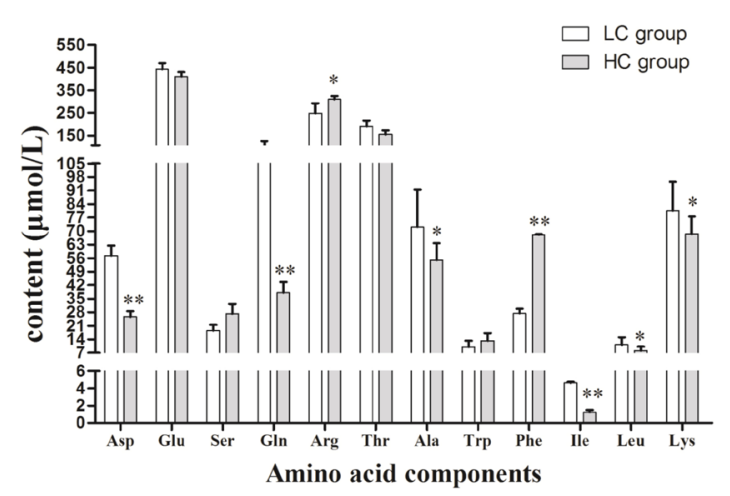

Figure 3. Effects of the high-concentrate $(\mathrm{HC})$ diet on the amino acid profile in milk. Data are expressed as mean \pm SE compared with the LC cattle. $* \mathrm{P}<0.05$ and $* * \mathrm{P}<0.01$ indicate statistically significant differences when compared with the LC group. 


\section{Gene expression}

Figure 4 shows the effect of the HC diet on mammary cytokine gene expression. interleukin-8 (IL-8), C-C motif chemokine ligand (CCL5), and lactalbumin alpha ( $\alpha$-LA) mRNA expression levels were significantly lower $(\mathrm{P}<0.05)$ in the HC group than in the LC group.

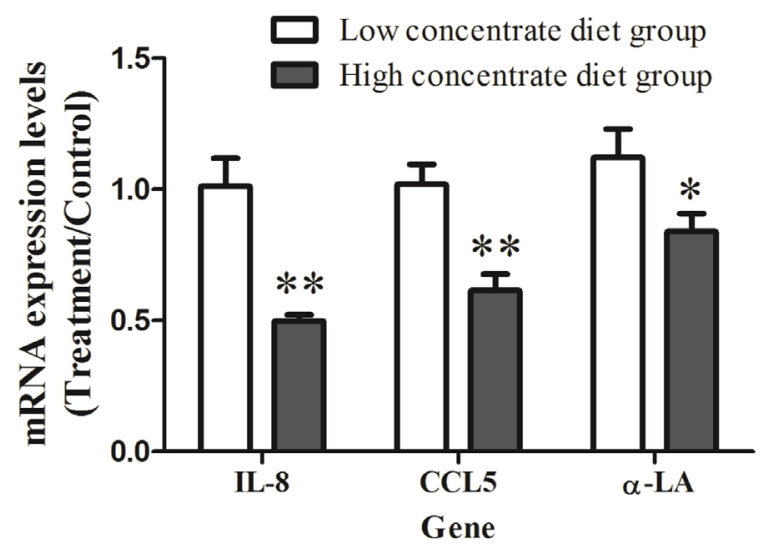

Figure 4. mRNA expression of interleukin-8 (IL-8), C-C motif chemokine ligand (CCL5), and lactalbumin alpha $(\alpha-\mathrm{LA})$ in the mammary. RNA was extracted from mammary, reverse transcribed to cDNA, and then analyzed by qRCR. The experiments were repeated three times. Data are presented as mean $\pm \mathrm{SE}, * \mathrm{P}<0.05$ indicates statistically significant differences when compared with the LC group. ${ }^{* *} \mathrm{P}<0.01$ indicates statistically significant differences when compared with the LC group.

\section{DISCUSSION}

The goal of this study was to characterize the milk and mammary health of lactating dairy cattle during the transition from a LC to $\mathrm{HC}$ diet. To achieve this, we established a controlled feeding protocol to minimize variation in animal diet feeding intake (ADFI) which is a common occurrence in cattle fed a rapidly fermentable diet ad libitum (Penner et al., 2009). NAG is an acidic hydrolase, located within lysosomes, and widely present in all tissues. Milk NAG is mainly derived from mammary epithelial cells and leukocytes. Studies by Leitner et al. (2003) showed that milk NAG activity significantly increased and mammary epithelial cells were damaged during mastitis. Therefore, NAG activity can be used as a sensitive index of mammary epithelial cells destruction. In the healthy mammary gland $\left(<10^{-5}\right.$ somatic cells/ $\mathrm{mL}$ milk), most viable somatic cells are macrophages and lymphocytes, with a few neutrophils and epithelial cells (Kehrli and Shuster, 1994). In the present study, we determined milk NAG activity and SCCs in HC-feeding cattle throughout the treatment period. The results showed that the $\mathrm{HC}$ diet can significantly increase milk NAG activity (Figure 2B). Figure 2A shows that the average SCC was higher in HC-fed cattle, achieving 166,733 cells $/ \mathrm{mL}$, but did not achieve the threshold of 205,000 cells $/ \mathrm{mL}$ (Rodrigues et al., 2009). These results were similar to those of our previous research, which showed that feeding a $\mathrm{HC}$ diet to cattle depressed milk quality (Xie et al., 2015b). However, in the present study, the SCC content and NAGase activity were higher than observed in our previous study (Xie et al., 2015b), because here we extended the experimental period. We therefore hypothesized that cattle mammary epithelial

Genetics and Molecular Research 16 (1): gmr16019204 
cells may suffer from sub-clinical mastitis when animals are fed a $\mathrm{HC}$ diet over a relatively long experimental period.

In contrast to the results obtained for milk NAG activity and SCC, the HC-fed cattle displayed percentage of milk production increased also, but decreased the percentage of milk fat and milk protein, and milk protein yield. Previous studies have shown that components of milk, such as fat, are negatively correlated with SCC (Burriel, 1997). Of the components of milk production measured, milk protein in $\mathrm{HC}$ cattle displayed the largest proportional increase, whereas milk fat percentage and yield decreased. Crist et al. (1982) estimated economic losses caused by lost milk production as a result of sub-clinical mastitis but did not specify losses by etiologic agent. Thus, we speculate that decreasing the synthesis of milk fat could play an important role in resistance to sub-clinical mastitis. However, further study of the relationship between feeding and sub-clinical mastitis in dairy cattle appear to be warranted.

In this study, mixtures consisting of the 15 standard known AAs were prepared and analyzed. We describe changes in 12 amino acids in milk, which were unambiguously separated and accurately marked based on the eluting peaks of standard AAs. In vivo, AAs are important products of protein decomposition, representing a "nodal point" in the dynamics of protein metabolism, especially as biological micro-molecules. Therefore, albuminolysis and the utilization of $\alpha$-keto acids can be used to transform glycogenic amino acids into glucose during metabolism (Battezzati and Riso, 2002). Under all metabolic conditions, amino acids lose their amino groups to form $\alpha$-keto acids, which constitute the "carbon skeletons" of amino acids. The $\alpha$-keto acids undergo oxidation to form $\mathrm{CO}_{2}$ and $\mathrm{H}_{2} \mathrm{O}$ or, often more importantly, provide three- and four-carbon units that can be converted by gluconeogenesis into glucose, providing fuel for the brain, skeletal muscles, and other tissues. As shown in Figure 3, the decrease in glycogenic amino acids indicated that the HC-fed cattle had sufficient energy for metabolism, and reduced albuminolysis or $\alpha$-keto acids were used in the mammary gland during the experiment. Therefore, $\alpha$-keto acids are an important intermediate product used to provide energy or raw materials for protein synthesis (Wu, 2009). Recent studies have found that AAs play important roles as signaling molecules in the regulation of protein synthesis (Liu et al., 2002; Jefferson and Kimball, 2003). In a study by Wang and Proud (2008), AAs could change the degree of phosphorylation of eukaryotic initiation factors. Notably, Gln was significantly decreased in HC-fed cattle, indicating that protein synthesis increased in these animals, which is consistent with the findings of previous studies showing that Gln can affect protein synthesis by regulating the translational initiation phase (Brasse-Lagnel et al., 2009).

Recent work by Rennie et al. (2006) revealed that the efficiency of BCAA oxidization to ATP was significantly higher than that for other amino acids, when the body needs AA as an energy source. Similarly, Laferrère et al. (2011) suggested that reduced blood BCAA might be associated with improved regulation of blood sugar. Our results showed that the BCAA content was remarkably lower in the HC group compared with the LC group, including Leu and Ile. As shown in Figure 3, the results revealed that the BCAA content decreased as it was used to supply energy or consumed during mammary cytokine synthesis in order to provide resistance to sub-clinical mastitis. Although the exact mechanisms underlying the protein synthesis response by AA regulation is unknown, in vitro experiments have shown that BCAA, particularly leucine, affects the mTOR pathway in the brain. These signals decrease food intake and increase the basic metabolic rate (Cota et al., 2006). Our finding of decreased DMI is consistent with the findings of Cota et al. (2006). Recent work by Burgos et al. (2010) and Toerien et al. (2010) reported that the mTOR pathway has a significant regulatory effect

Genetics and Molecular Research 16 (1): gmr16019204 
on milk protein synthesis. Particularly, p70-S6 kinase can affect the allocation and modification of protein precursors by mTOR pathway to regulate translation. Thus, we speculate that mTOR signaling pathways associated with AAs could play an important role in regulating protein synthesis in $\mathrm{HC}$-feeding cattle. Milk protein was also found to be decreased in $\mathrm{HC}$-feeding cattle.

Changes in AAs show that the $\mathrm{HC}$ diet fed can remarkably degrade the concentration of glycogenic AAs and BCAA in milk. These differential changes of AA content offer new insight into protein metabolism in the mammary in response to a $\mathrm{HC}$ diet. Although the current study is based on a small sample of dairy cows, the findings will garner the attention of experts and enhance our knowledge on the effects of a HC diet on milk components and mammary health. Furthermore, they may lead to the development novel technological or feeding strategies to mitigate the detrimental effects of sub-clinical mastitis to improve milk quality. Nonetheless, future research is necessary with larger samples.

\section{Conflicts of interest}

The authors declare no conflict of interest.

\section{ACKNOWLEDGMENTS}

Research supported by the Initial Funding of Jinshan College of Fujian Agriculture and Forestry University (\#Z150701).

\section{REFERENCES}

Battezzati A and Riso P (2002). Amino acids: fuel, building blocks for proteins, and signals. Nutrition 18: 773-774. http:// dx.doi.org/10.1016/S0899-9007(02)00898-5

Booth JM, Heeschen W and Saran A (1995). Milk enumeration of somatic cells. International IDF Standard 148-1:2009.

Brasse-Lagnel C, Lavoinne A and Husson A (2009). Control of mammalian gene expression by amino acids, especially glutamine. FEBS J. 276: 1826-1844. http://dx.doi.org/10.1111/j.1742-4658.2009.06920.x

Brouillette E and Malouin F (2005). The pathogenesis and control of Staphylococcus aureus-induced mastitis: study models in the mouse. Microbes Infect. 7: 560-568. http://dx.doi.org/10.1016/j.micinf.2004.11.008

Burgos SA, Dai M and Cant JP (2010). Nutrient availability and lactogenic hormones regulate mammary protein synthesis through the mammalian target of rapamycin signaling pathway. J. Dairy Sci. 93: 153-161. http://dx.doi.org/10.3168/jds.2009-2444

Burriel AR (1997). Dynamics of intramammary infection in the sheep caused by coagulase-negative staphylococci and its influence on udder tissue and milk composition. Vet. Rec. 140: 419-423. http://dx.doi.org/10.1136/vr.140.16.419

Capuco AV, Ellis SE, Hale SA, Long E, et al. (2003). Lactation persistency: insights from mammary cell proliferation studies. J. Anim. Sci. 81 (Suppl 3): 18-31. http://dx.doi.org/10.2527/2003.81suppl_318x

Cota D, Proulx K, Smith KA, Kozma SC, et al. (2006). Hypothalamic mTOR signaling regulates food intake. Science 312: 927-930. http://dx.doi.org/10.1126/science.1124147

Crist WL, Heider LE, Sears PM, Barr HL, et al. (1982). Effectiveness of educational efforts in implementing mastitis control procedures in commercial dairy herds. J. Dairy Sci. 65: 828-834. http://dx.doi.org/10.3168/jds.S0022-0302(82)82272-8

DeGraves FJ and Fetrow J (1993). Economics of mastitis and mastitis control. Vet. Clin. North Am. Food Anim. Pract. 9; 421-434. http://dx.doi.org/10.1016/S0749-0720(15)30611-3

Jefferson LS and Kimball SR (2003). Amino acids as regulators of gene expression at the level of mRNA translation. $J$. Nutr. 133 (Suppl 1): 2046S-2051S.

Kehrli ME, Jr. and Shuster DE (1994). Factors affecting milk somatic cells and their role in health of the bovine mammary gland. J. Dairy Sci. 77: 619-627. http://dx.doi.org/10.3168/jds.S0022-0302(94)76992-7

Laferrère B, Reilly D, Arias S, Swerdlow N, et al. (2011). Differential metabolic impact of gastric bypass surgery versus dietary intervention in obese diabetic subjects despite identical weight loss. Sci. Transl. Med. 3: 80re2. http://dx.doi. org/10.1126/scitranslmed.3002043

Genetics and Molecular Research 16 (1): gmr16019204 
Leitner G, Chaffer M, Zamir S, Mor T, et al. (2001). Udder disease etiology, milk somatic cell counts and NAGase activity in Israeli Assaf sheep throughout lactation. Small Rumin. Res. 39: 107-112. http://dx.doi.org/10.1016/S0921$\underline{4488(00) 00190-5}$

Leitner G, Chaffer M, Caraso Y, Ezra E, et al. (2003). Udder infection and milk somatic cell count, NAGase activity and milk composition-fat, protein and lactose-in Israeli-Assaf and Awassi sheep. Small Rumin. Res. 49: 157-164. http:// dx.doi.org/10.1016/S0921-4488(03)00079-8

Liu Z, Jahn LA, Wei L, Long W, et al. (2002). Amino acids stimulate translation initiation and protein synthesis through an Akt-independent pathway in human skeletal muscle. J. Clin. Endocrinol. Metab. 87: 5553-5558. http://dx.doi. org/10.1210/jc.2002-020424

Mansfeld R, Mansfeld S and Santlb B (2001). New aspects regarding the use of the milk electrical conductivity as aparameter for routine diagnostics in dairy production medicine program. Page 488-489, 2nd. Int Symposium on Bovine Mastitis and Milk Quality, Vancouver, CA.

Miglior F, Muir BL and Van Doormaal BJ (2005). Selection indices in Holstein cattle of various countries. J. Dairy Sci. 88: 1255-1263. http://dx.doi.org/10.3168/jds.S0022-0302(05)72792-2

Penner GB, Taniguchi M, Guan LL, Beauchemin KA, et al. (2009). Effect of dietary forage to concentrate ratio on volatile fatty acid absorption and the expression of genes related to volatile fatty acid absorption and metabolism in ruminal tissue. J. Dairy Sci. 92: 2767-2781. http://dx.doi.org/10.3168/jds.2008-1716

Rennie MJ, Bohé J, Smith K, Wackerhage H, et al. (2006). Branched-chain amino acids as fuels and anabolic signals in human muscle. J. Nutr. 136 (Suppl): 264S-268S.

Rodrigues AC, Cassoli LD, Machado PF and Ruegg PL (2009). Short communication: evaluation of an on-farm test to estimate somatic cell count. J. Dairy Sci. 92: 990-995. http://dx.doi.org/10.3168/jds.2008-1216

Seifu E, Dokin EF and Buys EM (2007). Potential of lactoperoxidase to diagnose subclinical mastitis in goat. Small Rumin. Res. 69: 154-158. http://dx.doi.org/10.1016/j.smallrumres.2006.01.005

Toerien CA, Trout DR and Cant JP (2010). Nutritional stimulation of milk protein yield of cows is associated with changes in phosphorylation of mammary eukaryotic initiation factor 2 and ribosomal s6 kinase 1. J. Nutr. 140: 285-292. http://dx.doi.org/10.3945/jn.109.114033

Valde JP, Lystad ML, Simensen E and Østerås O (2007). Comparison of feeding management and body condition of dairy cows in herds with low and high mastitis rates. J. Dairy Sci. 90: 4317-4324. http://dx.doi.org/10.3168/jds.2007-0129

Wang X and Proud CG (2008). A novel mechanism for the control of translation initiation by amino acids, mediated by phosphorylation of eukaryotic initiation factor 2B. Mol. Cell. Biol. 28: 1429-1442. http://dx.doi.org/10.1128/ MCB.01512-07

Whitley L (2010). The world dairy situation. Int. J. Dairy Technol. 63: 471-472. http://dx.doi.org/10.1111/j.1471$\underline{0307.2010 .00573 . \mathrm{x}}$

Wu G (2009). Amino acids: metabolism, functions, and nutrition. Amino Acids 37: 1-17. http://dx.doi.org/10.1007/ s00726-009-0269-0

Xie ZL, Ye PS, Zhang SK, Zhang YS, et al. (2015a). Endogenous LPS alters liver GH/IGF system gene expression and plasma lipoprotein lipase in goats. Physiol. Res. 64: 721-729.

Xie ZL, Ye PS, Zhang YS and Shen XZ (2015b). Effect of high-concentrate diet on amino acid transporter expression and milk quality in Holstein dairy cows. Genet. Mol. Res. 14: 5246-5257. http://dx.doi.org/10.4238/2015.May.18.16

Genetics and Molecular Research 16 (1): gmr16019204 